\title{
Detection of Australian gill-associated virus (GAV) and lymphoid organ virus (LOV) of Penaeus monodon by RT-nested PCR
}

\author{
Jeff A. Cowley*, Christine M. Dimmock, Kirsten M. Spann, Peter J. Walker \\ Cooperative Research Centre for Aquaculture, CSIRO Tropical Agriculture, PMB3, Indooroopilly 4068, Australia
}

\begin{abstract}
A highly sensitive test based on reverse transcription followed by nested polymerase chain reaction (RT-nPCR) was developed to detect the Australian yellow-head-like viruses, gill-associated virus (GAV) and lymphoid organ virus (LOV) of Penzeus monocion. The RT-nPCR detected viral RNA in as little as $10 \mathrm{fg}$ lymphoid organ total RNA isolated from GAV-infected $P$. monodon. Amplification of serial dilutions of a GAV CDNA clone showed that the nested PCR was sufficiently sensitive to detect a single genome equivalent using a DNA template. The specificity and sensitivity of the RT$\mathrm{nPCR}$ was also demonstrated using experimentally infected $P$. (Marsupenaeus) japonicus, where GAV sequences could be amplified from lymphoid organ and haemocyte RNA as early as $6 \mathrm{~h}$ post infection (p.i.), and from gills by $24 \mathrm{~h}$ p.i. In contrast, transmission electron microscopy (TEM) identified nucleocapsids and virions in lymphoid organ cells and haemocytes from Days 3 and 6 p.i., respectively, while there was no evidence of infection in gill cells at any time. The practical application of the RT-nPCR was demonstrated by screening healthy wild-caught $P$. monodon broodstock. The high prevalence (>98\%) of broodstock that were positive by RT-nPCR suggests that LOV is endemic in northern Queensland. In addition, results with lymphoid organ, gill and haemocyte RNA suggest that small gill biopsies may be best suited to the non-sacrificial testing of valuable broodstock. The speed and sensitivity of the RTnPCR make it a useful adjunct to TEM for diagnosing LOV/GAV infection of $P$. monodon, with the additional benefit that screening of gill biopsies may facilitate selection of LOV-free broodstock.
\end{abstract}

KEY WORDS: Yellow head virus (YHV) - Lymphoid organ virus (LOV) - Gill-associated virus (GAV) Penaeus monodon RT-PCR - Penaeid shrimp-Prawns

\section{INTRODUCTION}

We have recently described a rod-shaped, gill-associated virus (GAV) which was associated with mortalities of Penaeus monodon prawns at 4 farms in Queensland, Australia, in 1996 (Spann et al 1997). GAV is highly pathogenic, inducing mortalities from 4 to $5 \mathrm{~d}$ following experimental infection of subadult $P$. monodon. In diseased prawns, large numbers of helical nucleocapsids and enveloped virions appear in gill and lymphoid organ cells. Invariably, the lymphoid organ displays extensive cellular necrosis and structural degeneration (Spann et al. 1997). In morphology and cytopathology, GAV closely resembles yellow

\footnotetext{
•E-mail: jeff.cowley@tag.csiro.au
}

head virus (YHV) from Thailand (Boonyaratpalin et al. 1993, Chantanachookin et al. 1993, Wongteerasupaya et al. 1995). However, GAV does not induce the pale to yellow body colouration described for YHV, and mortality is usually preceded by a pink to red body colouration. Prior to the identification of GAV, a virus with similar morphology was reported to be common in healthy $P$. monodon in Queensland (Spann et al. 1995). Unlike GAV, lymphoid organ virus (LOV) infection appeared to be restricted to hypertrophied cells in discrete foci or 'spheroids' in the lymphoid organ. LOV is non-pathogenic, does not cause extensive cellular necrosis and has not been observed in gill tissue

Recent molecular studies of YHV and GAV have shown that they are closely related but distinct viruses which are likely to be classified in the family Coron- 
aviridae (Cowley et al. 1999). Wongteerasupaya et al. (1995) demonstrated that YHV contains a singlestranded RNA genome. Nadala et al. (1997a) subsequently showed that the YHV genome is $-22 \mathrm{~kb}$ long and identified 4 major virion proteins $(170,135,67$ and $22 \mathrm{kDa}$ ) of which the $135 \mathrm{kDa}$ protein is glycosylated. Tang \& Lightner (1999) have amplified reverse transcription-polymerase chain reaction (RT-PCR) products from cDNA synthesised using a primer of opposite sense to a putative coding sequence to show that YHV genomic RNA is likely to be of positive polarity. We have recently determined the nucleotide sequence of the GAV genome and established that it is indeed a (+) RNA virus which contains sequence homologies and a genome organisation, including large overlapping ORF1a and ORF1b polyprotein genes translated via a -1 ribosomal frameshift site, characteristic of toro- and coronaviruses (Cowley et al. unpubl.). Comparative sequence analysis of 3 corresponding regions of the ORF1b gene has indicated that YHV and GAV are closely related viruses that may be regarded as different geographic topotypes (Cowley et al. 1999).

In this paper, we describe a sensitive and specific RT-nested PCR (RT-nPCR) for detecting GAV in infected prawn tissues. The test is applied to the detection of GAV in total RNA isolated from lymphoid organ, gill and haemocytes of healthy and clinically diseased Penaeus monodon and from P. (Marsupenaeus) japonicus infected experimentally with GAV. Sequence analysis of PCR products amplified from healthy $P$. monodon indicates that LOV is a non-pathogenic variant of GAV. In addition, screening of hatchery broodstock suggests that LOV infection may be widespread in wild P. monodon from northern Queensland.

\section{MATERIALS AND METHODS}

Prawns. Healthy Penaeus monodon and $P$. japonicus were obtained from farms and hatcheries in south-east and northern Queensland between December 1996 and March 1998. P. monodon broodstock were captured from coastal waters in the Cairns, Innisfail and Townsville regions of northern Queensland. The broodstock were obtained either directly from a commercial trawler operator and tested prior to spawning or from hatcheries or CSIRO Marine Research, Cleveland, and tested subsequent to spawning. Prawns were sampled within 1 to $2 \mathrm{~d}$ of their acquisition. Diseased $P$. monodon, displaying characteristic clinical symptoms and histological evidence of GAV infection (Spann et al. 1997), were obtained from a pond at a farm in south-east Queensland that had experienced mortalities in March 1997
Virus infections. The prototype GAV isolate used to generate cDNA clones originated from clinically diseased Penaeus monodon collected from farm $\mathrm{A}$ in northern Queensland in 1996 (Spann et al. 1997). Healthy $P$. monodon ( 15 to $20 \mathrm{~g}$ ) were injected with $5 \mu \mathrm{l}$ $\mathrm{g}^{-1}$ body weight of head extracts of GAV-infected prawns as described previously (Spann et al. 1997). $P$. monodon deaths began at $4 \mathrm{~d}$ post infection (p.i.), and at $6 \mathrm{~d}$ p.i. lymphoid organ and gill tissues were isolated, snap frozen on dry ice and stored in liquid nitrogen until used for RNA isolation. Haemolymph 0.5 to $1.0 \mathrm{ml}$ ) was collected by cardiac puncture directly into $1 \mathrm{ml}$ ice-cold modified arsenals anticoagulant (19.3 mM sodium citrate, $239.8 \mathrm{mM} \mathrm{NaCl}, 182.5 \mathrm{mM}$ glucose, 6.2 mM EDTA, pH 7.3) (van de Braak et al. 1996). Haemocytes were collected by microcentrifugation at $5000 \times g$ for $2 \mathrm{~min}$, resuspended in $1 \mathrm{ml}$ phosphate-buffered saline (PBS), recentrifuged and the haemocyte pellet was stored at $-70^{\circ} \mathrm{C}$.

To follow the progress of GAV infection in a susceptible LOV-free host, juvenile Penaeus japonicus (12 to $14 \mathrm{~g}$ ) were inoculated as described above. Lymphoid organs, gills and haemocytes were pooled from 2 prawns sampled at 6, 24, and $48 \mathrm{~h}$ and on Days 3, 6, 9, 12 and 15 p.i. as described above and stored under liquid nitrogen until used for total RNA isolation. At the same times p.i., haemocytes and cephalothorax tissue samples from 2 prawns were also processed for histology and transmission electron microscopy (TEM).

Light and electron microscopy. Histological examinations of prawn cephalothorax tissues fixed in Davidson's fixative were conducted as described previously (Spann et al. 1997). Lymphoid organ, gill and haemocyte tissues were also fixed in modified Karnovsky's reagent and processed for TEM to confirm the presence of LOV/GAV and to quantify nucleocapsids and virions (Spann et al. 1997).

RNA isolation. In general, total RNA was extracted from 50 to $100 \mathrm{mg}$ lymphoid organ, gill or haemocytes of healthy and GAV-infected prawns by homogenisation in $750 \mu \mathrm{l}$ TRIzol-LS ${ }^{\mathrm{rM}}$ (Life Technologies) using a pellet pestle according to the manufacturer's instructions. RNA was resuspended in diethylpyrocarbonate (DEPC)-water, quantified by spectrophotometry $\left(A_{260 \mathrm{~nm}}\right)$ and stored at $-70^{\circ} \mathrm{C}$. All reagents and tissue samples were handled in a separate laboratory using a laminar flow cabinet and aerosol-resistant barrier pipette tips to prevent carry-over contamination with PCR products

Random PCR amplification and cloning of GAV cDNA. Lymphoid organ total RNA was isolated from Penaeus monodon infected experimentally with GAV as described above. RNAs were resolved in $0.6 \%$ LMP agarose (Life Technologies)-TAE gels containing $0.5 \mu \mathrm{g} \mathrm{ml}^{-1}$ ethidium bromide (Sambrook et al. 1989). 
Fig. 1. Nucleotide and deduced amino acid sequence of the 781 bp GAV (gill-associated virus) cDNA clone pG12 indicating the positions of the PCR primers GAV-1 $\left(A^{259}-C^{281}\right)$, GAV-2 $\left(C^{566}-C^{586}\right), G A V-5\left(A^{31}-C^{50}\right)$ and GAV-6 $\left(G^{628}-A^{648}\right)$. Sequence variations identified in 2 clones of a $317 \mathrm{bp}$ RT-nPCR product amplified from a healthy Penaeus monodon infected with LOV (lymphoid organ virus) (see Fig. 2) are shown above the GAV sequence

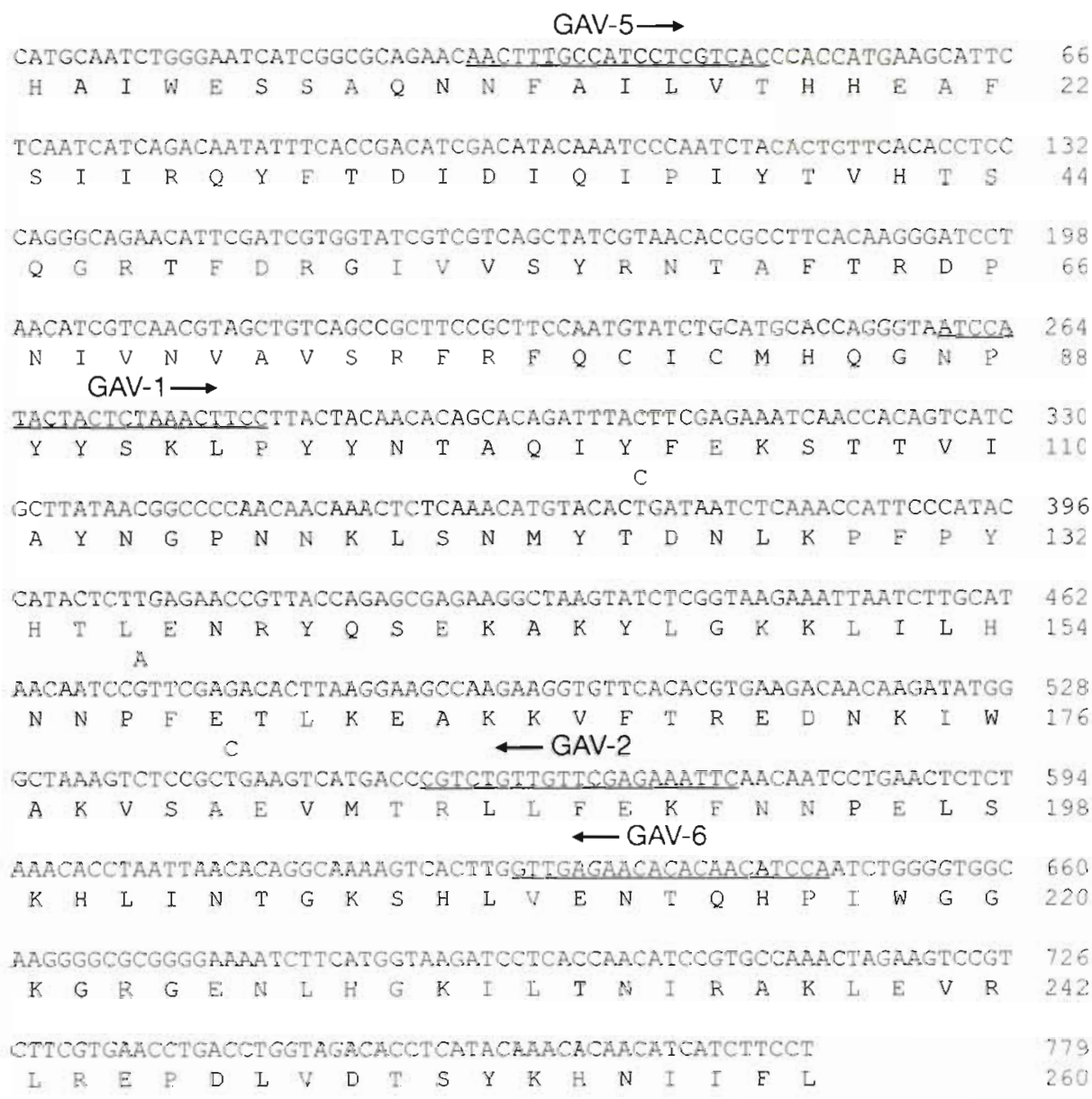

RT-PCR. Total RNA (100 ng) was denatured in the presence of $35 \mathrm{pmol}$ of each primer (GAV-5 and GAV6) by heating at $98^{\circ} \mathrm{C}$ for $8 \mathrm{~min}$ in $6 \mu \mathrm{l} \mathrm{DEPC}$-water containing $0.5 \mu$ l deionised formamide and quenched on dry ice. cDNA was synthesised by the addition of $2 \mu \mathrm{l}$ Superscript II buffer $\times 5,1 \mu \mathrm{l} 100 \mathrm{mM}$ DTT, $0.5 \mu \mathrm{l}$ $10 \mathrm{mM} \mathrm{dNTPS} 20 \mathrm{U}$ rRNasin ${ }^{\mathrm{MM}}$ (Promega) and $100 \mathrm{U}$ Superscript II reverse transcriptase (Life Technologies) and DEPC-water to $10 \mu \mathrm{l}$, and the reaction was incubated at $42^{\circ} \mathrm{C}$ for $1 \mathrm{~h}$ followed by heating at $99^{\circ} \mathrm{C}$ for 5 min before quenching on ice. To determine the sensitivity of the RT-PCR, 10 -fold dilutions of GAVinfected lymphoid organ RNA from Penaeus monodon were diluted in $100 \mathrm{ng} \mu \mathrm{l}^{-1}$ uninfected $P$. japonicus lymphoid organ total RNA.

One-tenth of the cDNA reaction $(1 \mu \mathrm{l}=10 \mathrm{ng} \mathrm{RNA})$ was amplified in $50 \mu \mathrm{l}$ using Taq buffer $(10 \mathrm{mM}$ Tris$\mathrm{HCl} \mathrm{pH} \mathrm{9.0,50} \mathrm{mM} \mathrm{KCl,0.1 \%} \mathrm{Triton} \mathrm{X-100),} 1.5 \mathrm{mM}$ $\mathrm{MgCl}_{2}, 35$ pmol each primer GAV-5 and GAV-6 and $200 \mu \mathrm{M}$ dNTPs overlaid with $50 \mu \mathrm{l}$ liquid paraffin. PCRs were initiated using a 'hot-start' protocol (Chou et al. 1992) in which the reaction was heated at $85^{\circ} \mathrm{C}$ for $5 \mathrm{~min}$ prior to the addition of $2.5 \mathrm{U}$ Taq polymerase nucleotide Synthesiser. 
(Promega). DNA was amplified by 30 cycles of $95^{\circ} \mathrm{C} / 1 \mathrm{~min}, 58^{\circ} \mathrm{C} / 1 \mathrm{~min}$, and $72^{\circ} \mathrm{C} / 40 \mathrm{~s}$, followed by $72^{\circ} \mathrm{C} / 10 \mathrm{~min}$ final extension and $20^{\circ} \mathrm{C}$ hold using either a Corbett Research or Omnigene (Hybaid) thermal cycler. PCR products $(10 \mu \mathrm{l})$ were resolved in $2 \%$ agarose-TAE gels containing $0.5 \mu \mathrm{g} \mathrm{ml}^{-1}$ ethidium bromide.

Nested PCR. When the result of the primary RT-PCR was negative or inconclusive, $0.5 \mu \mathrm{l}$ of the primary PCR was amplified by nested PCR as above in a $50 \mu \mathrm{l}$ reaction volume using primers GAV-1 and GAV-2. In some cases, $5 \mu$ l of the RT-PCR was used. Nested PCR conditions were as for the primary PCR except that the extension time was reduced to $30 \mathrm{~s}$ and number of cycles was reduced to 20 . Nested PCR aliquots (10 $\mu 1)$ were analysed in $2 \%$ agarose-TAE gels. When a result was still negative, the complete RT-nPCR was repeated with up to 5 aliquots of the total RNA sample. All PCR reagents were handled in a laminar flow cabinet using aerosol-resistant tips to avoid contamination. Primary RT-PCR products were handled in a separate work area to that in which nested PCRs were performed.

Sequencing analysis. For sequencing, nested PCR products were purified using a QIAquick column (QIAGEN) and cloned by ligation into pGEM-T and transformation of competent Escherichia coli DH5- $\alpha$ host cells as described previously (Cowley et al. 1999). Plasmid DNA was prepared using a RPM kit (BIO 101) and automated sequencing of inserts was conducted using universal M13/pUC forward and reverse primers, ThermoSequenase ${ }^{\mathrm{TM}}$ dye-terminator reagent (Amersham) and an automated ABI Model377 sequencing apparatus (Applied Biosystems Inc.) at the Australian Genome Research Facility, University of Queensland

Gill biopsies. Six male and 4 female healthy, mature Penaeus monodon (28 to $35 \mathrm{~g}$ ), which had not spawned in captivity, were collected from a hatchery in northern Queensland and held in the aquarium facility at CSIRO Tropical Agriculture, Brisbane, for 25 d. Gill biopsies were performed on 5 of the 10 prawns $(3$ males and 2 females) by holding the prawns firmly with the dorsal side against a flat surface and gently lifting the left gill cover to expose the 2 posterior primary gill filaments. The inner filament was removed using flame-sterilised scissors, leaving approximately 1.5 to $2 \mathrm{~mm}$ of the filament base. Prawns were monitored for mortality and wound healing for $5 \mathrm{wk}$. Total RNA was extracted using TRIzol-LS ${ }^{\mathrm{TM}}$ from gill biopsies: (1) pooled from the 2 females; (2) pooled from 2 males; and (3) from the remaining male. RT-nPCRs were performed and analysed as described above except that $1 \mu \mathrm{g}$ instead of $100 \mathrm{ng}$ RNA was used for cDNA synthesis.

\section{RESULTS}

\section{Specificity of the RT-nPCR}

The specificity of the RT-nPCR was determined using lymphoid organ RNA isolated from several sources including (1) healthy wild Penaeus monodon, (2) diseased farmed P. monodon and (3) P. monodon and $P$. japonicus infected experimentally with the prototype GAV isolate (Fig. 2). RT-PCR using primers GAV-5 and GAV-6 amplified the expected 618 bp product from $P$. monodon and $P$. japonicus, either naturally or experimentally infected with GAV. Nested PCR, using primers GAV-1 and GAV-2, readily amplified an internal 317 bp product from these primary RTPCR products. In addition, a nested PCR product was amplified from a healthy wild $P$. monodon infected asymptomatically with LOV at a level insufficient to generate a primary RT-PCR product. Nested PCR pro-

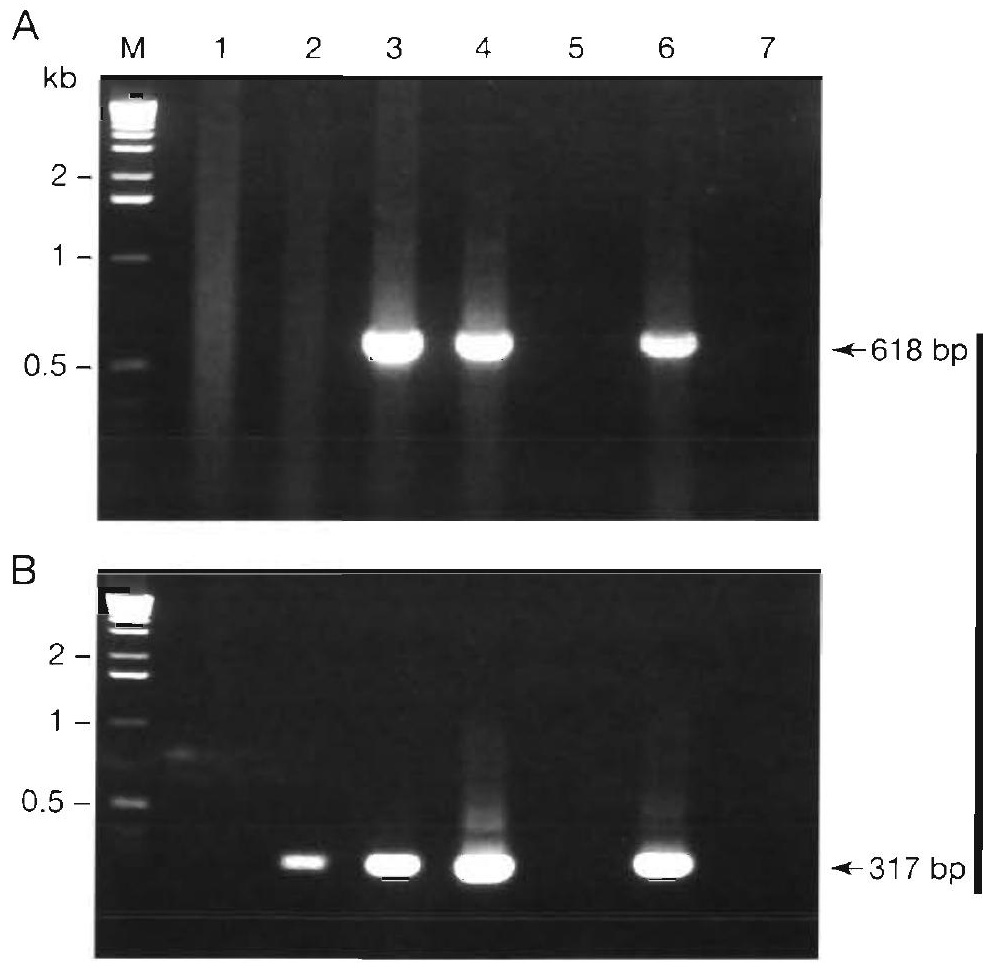

Fig. 2. RT-nPCR amplification of $10 \mathrm{ng}$ lymphoid organ RNA isolated from a healthy Penaeus monodon (lane 1), a healthy $P$. monodon infected asymptomatically with LOV (lane 2), $P$. monodon infected experimentally with GAV (lane 3), diseased $P$. monodon from a farm outbreak of GAV (lane 4), healthy $P$. japonicus (lane 5), and $P$. japonicus infected experimentally with GAV (lane 6). A negative RT control (lane 7) was as for lane 3 with no added Superscript II RT (A.) RT-PCR detection of 618 bp products, and (B) nested PCR detection of $317 \mathrm{bp}$ products amplified as described in Materials and methods' PCR products were resolved in a $2 \%$ agarose-TAE gel containing $0.5 \mu \mathrm{g} \mathrm{ml}^{-1}$ ethidium bromide. $\mathrm{M}=1 \mathrm{~kb}$ DNA ladder (Life Technologies) 
ducts were cloned and sequenced and the sequences compared to that of pG12 generated from the $22 \mathrm{kbp}$ dsRNA of the prototype GAV isolate. Sequences of 2 clones from $P$. monodon and 2 from $P$, japonicus infected with the prototype GAV were identical to the pG12 sequence. The sequences of 2 clones from the healthy $P$. monodon harbouring LOV were identical and displayed only $1.1 \%(3 / 274)$ nucleotide variation from pG12. None of the variations altered the coding sequence (see Fig. 1). No products were amplified from uninfected $P$. japonicus or from another overtly healthy $P$. monodon. RNA from GAV-infected $P$. monodon also failed to produce RT-nPCR products when reverse transcriptase was omitted, demonstrating that the primers were not amplifying an extraneous DNA template. In addition, the absence of RT-PCR inhibitors and the integrity of the control $P$. japonicus RNA were confirmed by RT-PCR amplification of an $848 \mathrm{bp}$ fragment of $18 \mathrm{~S}$ ribosomal RNA using primers designed for the rRNA sequence of $P$, aztecus (Kim \& Abele 1990) (data not shown).

It was not possible to test for cross-reactivity with a comprehensive range of viral pathogens of Penaeus monodon. However, nested PCR with the GAV-specific primers failed to amplify DNA isolated from $P$. monodon postlarvae infected with monodon baculovirus (MBV) or from purified white spot syndrome virus (WSSV) (data not shown). The integrity of the MBV and WSSV DNA was confirmed using the nested PCR reported by Belcher \& Young (1998) and by PCR using the PRDV P3/P4 primers reported by Kimura et al. (1996), respectively.

\section{Sensitivity and detection limit of the RT-nPCR}

To determine the detection limit of the nested PCR, serial 10-fold dilutions of purified plasmid DNA (pG12, $3824 \mathrm{bp}$ ) were amplified in a primary PCR using the primer pair GAV-5/GAV-6, and aliquots $(0.5 \mu \mathrm{l})$ were re-amplified in a secondary nested PCR using the primer pair GAV-1/GAV-2 (Fig. 3). Specific products were detected with $1 \mathrm{fg}$ DNA ( 240 genome equivalents) in the primary PCR and with 1 ag DNA ( 0.24 genome equivalents) in the nested PCR. As expected, detection sensitivity could not be enhanced by increasing the amount of primary product used in the nested PCR to $5 \mu l$.

The detection sensitivity of the RT-nPCR for viral RNA was determined using serial 10 -fold dilutions of total RNA from pooled lymphoid organs of Penaeus

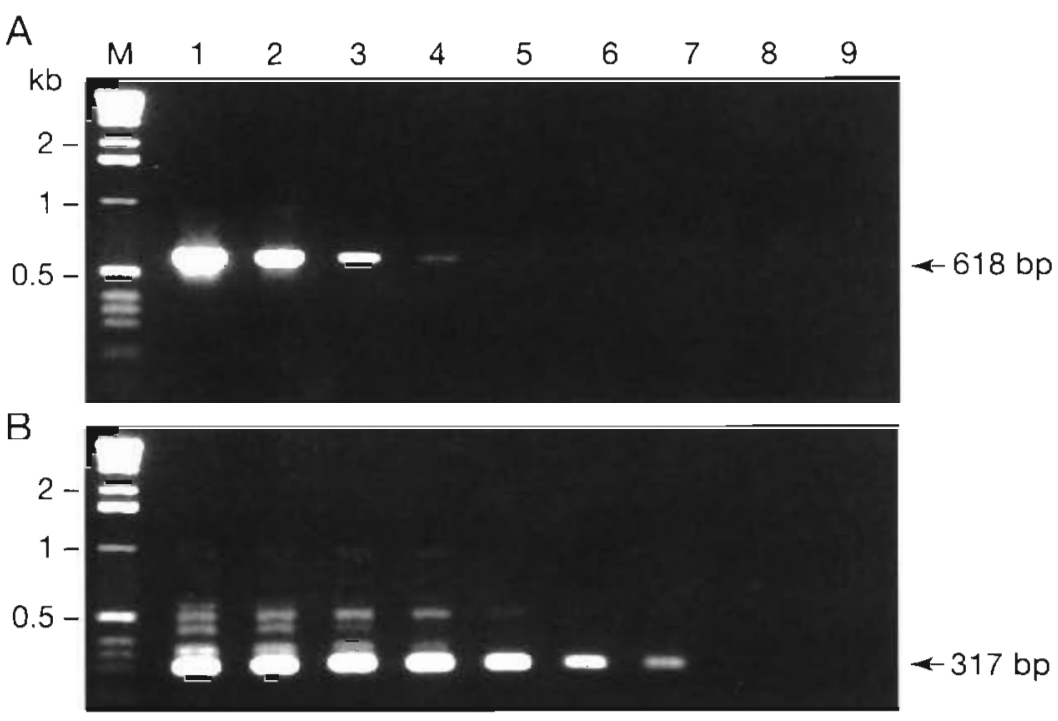

Fig. 3. Limit of detection of the primary PCR and the nested PCR. (A) PCR amplification of serial 10-fold dilutions containing $1 \mathrm{pg}$ to $0.1 \mathrm{ag}$ pG12 plasmid DNA using GAV-5/GAV-6 primers (lanes 1 to 8, respectively). Lane 9 represents a water control. (B) Nested PCR amplification of the primary PCRs (lanes 1 to 9) using GAV-1/GAV2 primers. PCR products were resolved as described in Fig. 2. $M=$ $1 \mathrm{~kb}$ DNA ladder (Life Technologies)

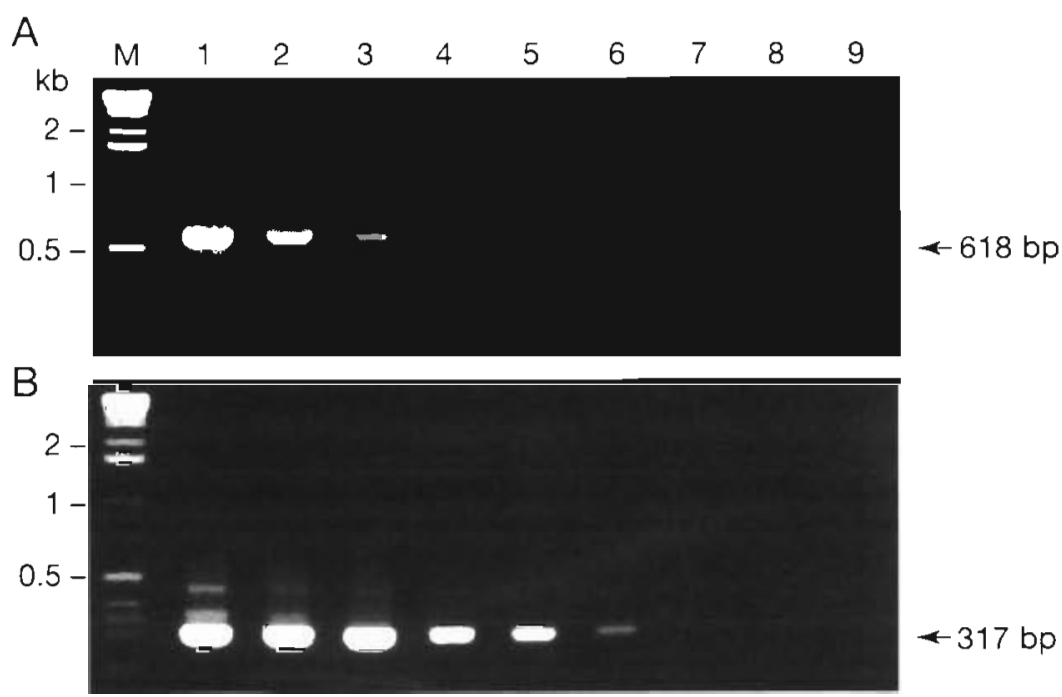

Fig. 4. Sensitivity of the RT-nPCR using a titration of lymphoid organ total RNA isolated from Penaeus monodon infected experimentally with GAV. (A) RT-PCR amplification of serial 10-fold dilutions containing $10 \mathrm{ng}$ to $1 \mathrm{fg}$ RNA (lanes 1 to 8 , respectively). P. japonicus lymphoid organ total RNA (100 ng, lane 9) was used as a negative control. (B) Nested PCR amplification of primary RT-PCRs (lanes 1 to 9). PCR products were resolved as described in Fig. 2. $M=1 \mathrm{~kb}$ DNA ladder (Life Technologies)

monodon infected experimentally with GAV (Fig. 4). Dilutions were prepared in $100 \mathrm{ng} \mathrm{ul}^{-1}$ uninfected $P$. japonicus lymphoid organ RNA to maintain a relatively constant amount of RNA for cDNA synthesis. GAV 


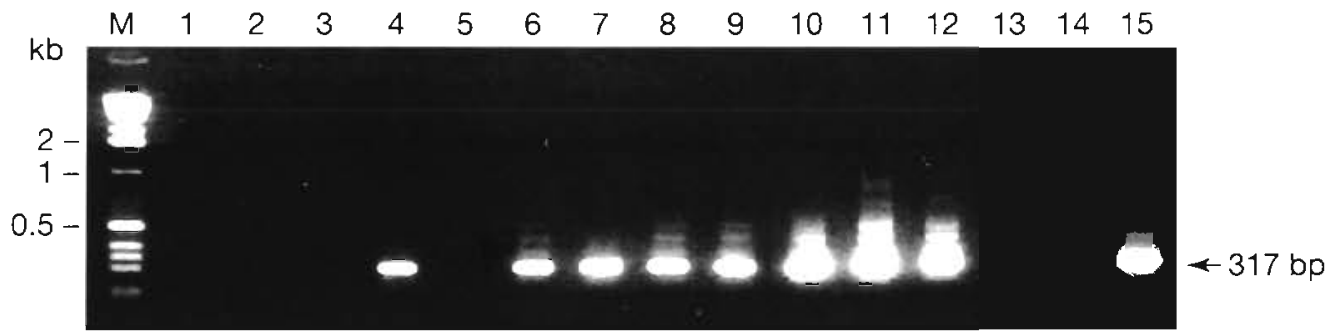

Fig. 5. Agarose gel electrophoresis of RT-nPCR products of GAV amplified from lymphoid organ (lanes 1, 4, 7, 10), gill (lanes 2, $5,8,11$ ), and haemocytes (lanes 3,6, 9, 12) of experimentally infected Penaeus japonicus at various times after inoculation. Amplifications were conducted using $10 \mathrm{ng}$ total RNA pooled from 2 prawns sampled prior to infection (lanes 1 to 3 ) and at $6 \mathrm{~h}$ (lanes 4 to 6), $24 \mathrm{~h}$ (lanes 7 to 9) and $48 \mathrm{~h}$ p.i. (lanes 10 to 12). Controls included water (lane 13), $10 \mathrm{ng}$ lymphoid organ total RNA from healthy $P$. japonicus (lane 14) and GAV-infected $P$. monodon (lane 15). The $317 \mathrm{bp} \mathrm{RT-nPCR} \mathrm{products} \mathrm{were} \mathrm{resolved} \mathrm{as} \mathrm{described}$ in Fig. 2. $M=1 \mathrm{~kb}$ DNA ladder (Life Technologies)

sequences present in $100 \mathrm{pg}$ total RNA were detected by RT-PCR. As observed with plasmid DNA, the nested PCR enhanced detection sensitivity by 1000 fold, allowing amplification of virus sequences from 100 fg RNA. Moreover, GAV sequences were detected in $10 \mathrm{fg}$ RNA when $5 \mu \mathrm{l}$ instead of $0.5 \mu$ l of the primary RT-PCR was used in the nested PCR (data not shown).

\section{Comparison of RT-nPCR with TEM}

To compare the sensitivity of the RT-nPCR with detection of GAV infection by histology and TEM, Penaeus japonicus were infected experimentally and 2 prawns were sampled at various times p.i. for lymphoid organs, gills and haemocytes. Juvenile $P$. japonicus are susceptible to GAV infection (Spann et al. unpubl.) and were used as an experimental model due to difficulties in obtaining LOV-free P. monodon. By RT-nPCR, GAV was detected in lymphoid organs and haemocytes from 6 h p.i. (Fig. 5). Retesting of gill RNA 3 times indicated that it was also weakly positive at this time (data not shown). At $24 \mathrm{~h}$ p.i., GAV was also readily detected in gill cells, and at 2 d p.i. all 3 tissue sources were clearly positive by the primary RT-PCR and yielded significantly increased amounts of the $317 \mathrm{bp}$ nested PCR product. Two infected $P$. japonicus were sampled at the same time points for histology and TEM. Histological evidence of GAV infection was observed in 1 prawn on Day 6 p.i. and in all prawns sampled from Day 12 p.i. In lymphoid organ tissue, TEM identified GAV nucleocapsids and virions in $\sim 10 \%$ of the cells on Day 3 p.i. and in up to $30 \%$ of the cells at later time points. GAV nucleocapsids were observed in haemocytes from Day 6 p.i. but there was no evidence of GAV infection in gill cells at any stage up to $15 \mathrm{~d}$ p.i.

\section{RT-nPCR screening of Penaeus monodon broodstock}

A preliminary assessment of the usefulness of the RT-nPCR in detecting asymptomatic LOV infection in various tissues was made using 7 male and 3 female healthy wild Penaeus monodon broodstock that were used in captive spawnings (Table 1). The primary RTPCR amplified LOV sequences from $10 / 10$ prawns using lymphoid organ RNA, from 9/10 prawns using gill RNA and from 4/9 prawns using haemocyte RNA. Nested PCR amplification of the primary RT-PCRs confirmed the positive status of equivocal $(+/-)$ results but revealed no additional positives.

RT-nPCR screening of lymphoid organ RNA from individual prawns was undertaken to determine the prevalence of LOV/GAV in Penaeus monodon broodstock sourced from northern Queensland, Australia. The results of testing broodstock originally captured from coastal waters in the Cairns, Innisfail and Townsville regions between September 1997 and March 1998

Table 1. RT-nPCR detection of LOV infection in wild-caught Penaeus monodon broodstock. +: 618 bp product amplified by RT-PCR with primers GAV-5 and GAV- $6 ; 317$ bp product amplified by $n P C R$ with primers GAV-1 and GAV-2. +/-: weakly positive in some cases in a background of non-specific PCR products. ND: not done

\begin{tabular}{|lccccccc|}
\hline Prawn & Sex & $\begin{array}{c}\text { Lymphoid organ } \\
\text { RT-PCR nPCR }\end{array}$ & \multicolumn{2}{c}{ Gill } & \multicolumn{2}{c|}{ Haemocytes } \\
& \multicolumn{3}{c}{ RT-PCR nPCR } & \multicolumn{2}{c}{ RT-PCR } & nPCR \\
\hline 1 & $\mathrm{M}$ & + & $\mathrm{ND}$ & + & + & $+/-$ & + \\
2 & $\mathrm{~F}$ & + & $\mathrm{ND}$ & + & + & - & - \\
3 & $\mathrm{~F}$ & + & $\mathrm{ND}$ & $+/-$ & + & - & - \\
4 & $\mathrm{M}$ & + & $\mathrm{ND}$ & + & + & + & + \\
5 & $\mathrm{M}$ & + & $\mathrm{ND}$ & $+/-$ & + & - & - \\
6 & $\mathrm{M}$ & + & $\mathrm{ND}$ & $+/-$ & + & - & - \\
7 & $\mathrm{~F}$ & + & $\mathrm{ND}$ & + & + & + & + \\
8 & $\mathrm{M}$ & + & $\mathrm{ND}$ & + & + & $+/-$ & + \\
9 & $\mathrm{M}$ & $+/-$ & + & $+/-$ & + & - & - \\
10 & $\mathrm{M}$ & + & $\mathrm{ND}$ & - & - & $\mathrm{ND}$ & $\mathrm{ND}$ \\
Total & & $10 / 10$ & & $9 / 10$ & $9 / 10$ & $4 / 9$ & $4 / 9$ \\
\hline
\end{tabular}


Table 2. Prevalence of LOV/GAV in Penaeus monodon broodstock determined by RT-nPCR testing of lymphoid organ RNA. Wild source: hatchery records indicated that prawns were captured from the (A) Innisfail, (B) Cairns and

(C) Townsville regions of northern Queensland, Australia

\begin{tabular}{|llccc|}
\hline $\begin{array}{l}\text { Wild } \\
\text { source }\end{array}$ & Hatchery & Date & $\begin{array}{c}\text { Broodstock } \\
\text { tested }\end{array}$ & $\begin{array}{c}\text { RT-nPCR } \\
\text { positive }\end{array}$ \\
\hline A & CSIRO & 25 Sep 1997 & 10 & 10 \\
A & Hatchery 1 & 13 Oct 1997 & 12 & 12 \\
B & Hatchery 2 & 14 Oct 1997 & 12 & 12 \\
C & Hatchery 3 & 27 Mar 1998 & 12 & 12 \\
A & Trawler & 5 Mar 1998 & 12 & 11 \\
Total & & 58 & 57 \\
arawns supplied direct from a trawler & \\
\hline
\end{tabular}

are shown in Table 2 . Of 58 broodstock tested, including the 10 reported above, 57 (98\%) were positive by RT-nPCR

\section{Clinical effects and RT-nPCR of gill biopsies}

The effects of collecting gill biopsies for RT-nPCR screening for LOV/GAV was assessed by monitoring wound healing and mortality in 5 adult Penaeus monodon. Melanisation of the gill cover at the point where it was lightly bent to gain access to the posterior gill filaments was observed $4 \mathrm{~d}$ after biopsy and persisted for the 5 wk prawns were maintained. No melanisation was observed at the biopsy site. One of the male prawns from which a biopsy was taken died during the $5 \mathrm{wk}$, as did 1 of 5 non-biopsied controls. Gill tissue pooled from the 2 female and 2 of the 3 male prawns tested positive by RT-PCR (Fig. 6). Nested PCR indicated that low levels of LOV were also present in the gills of the single male that was negative in the primary RT-PCR

\section{DISCUSSION}

The RT-nPCR test described here provides a rapid, specific and highly sensitive method for detecting GAV in prawn tissue. The RTnPCR also amplifies a product from Penaeus monodon asymptomatically infected with LOV. Sequence analysis of the 274 nucleotide internal region of the nested PCR product from LOV-infected prawns indicated $98.9 \%$ identity to the prototype GAV sequence. The 3 nucleotide differences in this region did not change the corresponding amino acid se- quence. More extensive sequence comparisons, including 3 additional GAV isolates and $>20$ LOV isolates from healthy prawns collected from the wild in different locations in northern Queensland, have identified similar high levels of sequence identity (Cowley et al. unpubl.). These findings strongly suggest that GAV and LOV represent variants of the same virus. As we have reported previously, this level of sequence homology contrasts with the $76.3 \%(209 / 274)$ nucleotide sequence identity in the same genomic region of GAV and a Thai YHV isolate, which represent distinct but closely related topotypes (Cowley et al. 1999).

Analysis of many captured and farmed Penaeus monodon infected asymptomatically with LOV has indicated that the quantities of the $618 \mathrm{bp}$ RT-PCR product can sometimes match levels obtained from GAV-infected diseased prawns (Cowley et al. unpubl.). However, some prawns are infected with LOV at levels below the detection limit of the primary RTPCR. Nested amplification of an internal 317 bp product provides additional specificity and enhanced sensitivity. The nested PCR is $10^{3}$ - to $10^{4}$-fold more sensitive than the primary $\mathrm{PCR}$ and can detect viral RNA in as little as $10 \mathrm{fg}$ of total lymphoid organ RNA. Amplification of GAV sequences from plasmid DNA indicates that the nested PCR will detect the theoretical limit of a single molecule. However, competitive RT-PCR methods using synthetic RNA 'mimics' will be required to accurately quantify the detection limits for viral RNA targets. The sensitivity of the RT-nPCR is also illustrated by its ability to detect GAV RNA in lymphoid organ, gill and haemocytes within 6 to $24 \mathrm{~h}$ following experimental infection of $P$. japonicus. This

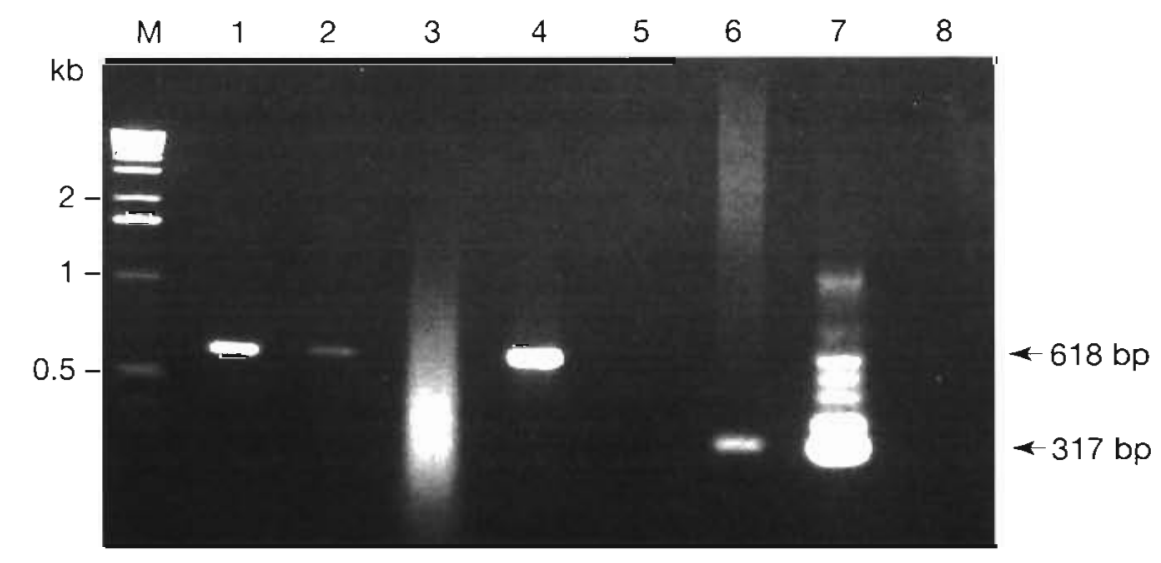

Fig. 6. Agarose gel electrophoresis of RT-nPCR products amplified from gill biopsies of adult Penaeus monodon infected asymptomatically with LOV. RT-PCR (lanes 1 to 5) and nested PCR (lanes 6 to 8) employed $100 \mathrm{ng}$ total RNA isolated from tissue pooled from 2 females (lane 1) and 2 males (lane 2) and from a single male prawn (lanes 3 and 6). Lymphoid organ total RNA (100 ng) from an LOV-infected $P$. monodon (lanes 4 and 7 ) and water (lanes 5 and 8 ) were used as controls. PCR products were resolved as described in Fig. $2 . M=1 \mathrm{~kb}$ DNA ladder (Life Technologies) 
is well before pathology is obvious by histological examination or viral nucleocapsids can be observed by TEM.

An RT-PCR test detecting YHV has recently been described (Wongteerasupaya et al. 1997). A 135 bp PCR product could be amplified from $10 \mathrm{fg}$ purified YHV RNA which, based on a genome length of $\sim 22 \mathrm{~kb}$, represents $\sim 820$ genome equivalents. The detection sensitivity of the PCR was enhanced 1000 -fold by Southern blotting using a digoxigenin-labelled DNA probe. It is unlikely, however, that this procedure would be used in routine diagnostic situations. The data reported here for GAV suggest that similar gains in sensitivity would be achieved by secondary amplification. However, the small size of the primary YHV product may restrict its usefulness as a template for nested PCR. Other in vitro diagnostic methods reported recently for YHV include immunological detection of viral proteins in infected prawn haemolymph by nitrocellulose-enzyme immunoassay (Lu et al. 1996) or Western blotting (Nadala et al. 1997b) using polyclonal YHV antisera. It is not yet known if LOV and GAV are sufficiently related to YHV to be detected by these tests. A non-radioactive in situ hybridisation test has also been developed to detect YHV in infected prawn tissues (Tang \& Lightner 1999). The level of sequence identity between GAV and YHV in the region used as a probe suggests that this test may be adapted to detect GAV infections (Cowley et al. 1999).

We have recently demonstrated that both the primary and nested GAV PCR primers will amplify a product from a YHV isolate from Thailand (Cowley et al. 1999). Sequence comparisons of this and 2 other corresponding regions of the ORF1b replicase gene indicate that GAV and this Thai YHV isolate represent distinct geographic topotypes. We have also reported that there are multiple sequence mismatches between GAV and YHV in the regions targeted by YHV primers $(10 \mathrm{~F} / 144 \mathrm{R})$ amplifying the $135 \mathrm{bp}$ product and that these primers do not amplify GAV RNA. Thus the GAV-5/GAV-6 primers, in combination with the YHV $10 \mathrm{~F} / 144 \mathrm{R}$ primers, may be useful in distinguishing yellow-head-like viruses from Australia and Thailand. There is a lack of information, however, on the YHV sequence targeted by the GAV-5/GAV-6 primers, and significant $(14.7 \%)$ nucleotide sequence divergence exists in the amplified region. We suggest that the GAV RT-nPCR should be applied cautiously for detecting YHV, as other isolates may vary in sequence from the Thai strain. Ultimately, as more sequence data become available, RT-PCR primers could be tailored for group-specific detection or for detection of variants from different locations. Such refined PCR tests may also be useful in differentiating pathogenic and nonpathogenic variants of GAV and YHV, and in deter- mining the origin of yellow-head-like viruses associated with disease outbreaks

The GAV RT-nPCR is currently being applied to monitor the prevalence of LOV infection in Penaeus monodon broodstock captured from coastal waters in northern Queensland and to screen other common prawn species. In the 1997-1998 summer grow-out season, $57 / 58$ (>98\%) of lymphoid organ RNA samples from healthy broodstock tested positive by PCR, suggesting that LOV is endemic in wild fisheries in northern Queensland. As the majority (45) of prawns were sourced from hatcheries subsequent to spawning, it is possible that the high infection rate was attributable to their maintenance in close confinement and/or spawning in captivity. However, the detection of LOV in 11 of 12 broodstock supplied directly from a commercial trawler operator does not lend support to the supposition that significant new infections occurred in the hatcheries.

As nested PCR tests are extremely sensitive, false positives may occur if due care is not exercised in both sample processing and test implementation. We have adopted practices that (1) minimize the likelihood of sample contamination, (2) monitor for potential false positives by the routine processing of mock negative samples and (3) maximize the chances of detecting low virus loads by repeated testing of RNA from negative prawns. Although only the final data are reported, several prawns sourced from northern Queensland were negative in the initial RT-nPCR but positive in subsequent analyses, suggesting they were infected at very low levels approaching the sensitivity limit of the test. It is unlikely that such infections would be apparent by diagnostic histology or TEM. Although such methods were not applied to all broodstock tested by RT-nPCR, ad hoc screening over several seasons (Spann unpubl.) corroborates our molecular data that LOV is highly prevalent in wild and farmed Penaeus monodon in Queensland. Further research will be required for direct correlations of the sensitivity and reproducibility of available diagnostic tests for LOV/GAV.

There is currently little data for yellow-head-like viruses on potential horizontal transmission during fertilization/spawning or vertical transmission from broodstock to larvae. In Thailand, YHV screening of Penaeus monodon broodstock by TEM has suggested that post-larval infection does not constitute a major route by which disease enters farms (Flegel et al. $1997 a, b)$. In Queensland, however, the close genetic relationship between LOV and GAV suggests a linkage between the high prevalence of asymptomatic LOV infection and outbreaks of GAV-related disease in farmed $P$. monodon. As the majority of broodstock utilised by hatcheries originates from wild stocks collected from only 2 locations, Innisfail and Cairns, in 
northern Queensland, this would have significant ramifications for the industry. The RT-nPCR test will assist in addressing the important issues relating to vertical transmission of LOV/GAV and in identifying LOV-free populations of $P$. monodon that may exist at other locations in northern Australia.

The discovery that 9 out of 10 gill RNA samples from healthy Penaeus monodon tested positive by RT-nPCR contrasts with the complete lack of TEM evidence of LOV infection in gill tissue (Spann et al. 1995, 1997). LOV may be present at very low levels either in very few gill cells or in haemolymph or circulating haemocytes that infiltrate the tissue. Alternatively, LOV may establish a persistent infection similar to that reported recently for a mammalian coronavirus (mouse hepatitis virus) in which low levels of viral RNA replication occur in the absence of infectious virus (Bergmann et al. 1998). We have also found that the RT-nPCR can detect LOV RNA in single gill filaments biopsied from healthy adult $P$. monodon. Moreover, the prawns appear not to be adversely affected by the biopsy. Although effects on spawning efficiency need to be determined, the good correlation between detection of LOV in lymphoid organs and gills suggests that RT$\mathrm{nPCR}$ testing of gill biopsies may find use in screening broodstock prior to spawning or in programs to establish specific pathogen-free (SPF) hatchery stocks.

Acknowledgements. The authors wish to thank CSIRO Marine Research at Cleveland, Gold Coast Marine Aquaculture, Rocky Point Prawn Hatchery, Seafarm Pty. Ltd and Tomei Australia for supplying prawns, Dr Parichart Burns for the dsRNA strand-separation protocol, Dr Iain East for supplying MBV-infected prawn DNA, Dr Tracey Harvey for supplying WSSV DNA. Mr Alan Donaldson for maintaining prawns and aquarium facilities and Mr Lee Cadogan for technical assistance.

\section{LITERATURE CITED}

Belcher CR, Young PR (1998) Colourmetric PCR based detection of monodon baculovirus (MBV) in whole Penaeus monodon postlarvae. J Virol Methods 74:21-20

Bergmann C, Dimacali E, Stohl S, Lai MMC, Tahara S, Marten N (1998) Variability of persistent MHV RNA sequences constituting immune and replicative-relevant domains. Virology 244:563-572

Boonyaratpalin S, Supamattaya K, Kasornchandra J, Direkbusaracom S, Aekpanithanpong U, Chantanachookin C (1993) Non-occluded baculo-like virus, the causative agent of yellow-head disease in the black tiger shrimp (Penaeus monodon). Fish Pathol 28:103-109

Chantanachookin C, Boonyaratpalin S, Kasornchandra J, Sataporn D, Ekpanithanpong U, Supamataya K, Sriurairatana S, Flegel TW (1993) Histology and ultrastructure reveal a new granulosis-like virus in Penaeus monodon affected by yellow-head disease. Dis Aquat Org 17:145-157
Chou Q, Russell M, Birch DE, Raymonmd J, Bloch W (1992) Prevention of pre-PCR mispriming and primer dimerisation improves low-copy number amplifications. Nucleic Acids Res 20:1717-1723

Cowley JA, Dimmock CM, Wongteerasupaya C, Boonsaeng V, Panyim S, Walker PJ (1999) Yellow head virus from Thailand and gill-associated virus from Australia are closely related but distinct viruses. Dis Aquat Org 36: $153-157$

Flegel TW, Sriurairatana S, Morrison DJ, Waiyakrutha N (1997a) Penaeus monodon captured broodstock surveyed for yellow-head virus and other pathogens by electron microscopy. In: Flegel TW, Menasveta P, Paisarnrat S (eds) Shrimp biotechnology in Thailand. National Center for Genetic Engineering and Biotechnology, Bangkok, p $37-43$

Flegel TW, Boonyaratpalin S, Withyachumnarnkul B (1997b) Progress in research on yellow-head virus and white-spot virus in Thailand. In: Flegel TW, MacRae IH (eds) Diseases in Asian Aquaculture III. Fish Health Section, Asian Fisheries Society, Manila, p 285-295

Froussard P (1992) A random-PCR method (rPCR) to construct whole cDNA library from low amounts of RNA. Nucleic Acids Res 20:2900

Kim W, Abele LG (1990) Molecular phylogeny of selected decapod crustaceans based on $18 \mathrm{~S}$ rRNA nucleotide sequences. J Crustac Biol 10:1-13

Kimura T, Yamano K, Nakano H, Momoyama K, Hiraoka M, Inouye K (1996) Detection of penaeid rod-shaped DNA virus (PRDV) by PCR. Fish Pathol 31:93-98

Lu Y, Tapay LM, Loh PC (1996) Development of a nitrocellulose-enzyme immunoassay for the detection of yellowhead virus from penaeid shrimp. J Fish Dis 19:9-13

Nadala ECB, Tapay LM, Loh PC (1997a) Yellow-head virus: a rhabdovirus-like pathogen of penaeid shrimp. Dis Aquat Org 31:141-146

Nadala ECB, Tapay LM, Cao S, Loh PC (1997b) Detection of yellowhead virus and Chinese baculovirus in penaeid shrimp by a Western blot technique. J Virol Methods 69: $39-44$

Sambrook J, Fritsch EF, Maniatis T (eds) (1989) Molecular cloning: a laboratory manual, 2nd edn. Cold Spring Harbor Laboratory Press, Cold Spring Harbor

Spann KM, Vickers JE, Lester RJG (1995) Lymphoid organ virus of Penaeus monodon from Australia. Dis Aquat Org 23:127-134

Spann KM, Cowley JA, Walker PJ, Lester RJG (1997) A yellow-head-like virus from Penaeus monodon cultured in Australia. Dis Aquat Org 31:169-179

Tang KFJ, Lightner DV (1999) A yellow head virus probe: nucleotide sequence and application to in situ hybridization. Dis Aquat Org 35:165-173

van de Braak CBT, Faber R, Boon JH (1996) Cellular and humoral characteristics of Penaeus monodon (Fabricius, 1798) haemolymph. Comp Haematol Int 6:194-203

Wongteerasupaya C, Sriurairatana S, Vickers JE, Akrajamorn A, Boonsaeng V, Panyim S, Tassanakajon A, Withyachumnarnjul B, Flegel TW (1995) Yellow-head virus of Penaeus monodon is an RNA virus. Dis Aquat Org 22:45-50

Wongteerasupaya $C$, Tongcheua $W$, Boonsaeng $V$, Panyim S, Tassanakajon A, Withyachumnarnjul B, Flegel TW (1997) Detection of yellow-head virus (YHV) of Penaeus monodon by RT-PCR amplification. Dis Aquat Org 31: 181-186

Submitted: May 12, 1999; Accepted: August 31, 1999

Proofs received from author(s): January 11, 2000 